\title{
ACPD
}

15, 33049-33075, 2015

This discussion paper is/has been under review for the journal Atmospheric Chemistry

and Physics (ACP). Please refer to the corresponding final paper in ACP if available.

\section{North Atlantic Oscillation model projections and influence on tracer transport}

NAO evolution and tracer transport

S. Bacer et al.

S. Bacer ${ }^{1}$, T. Christoudias ${ }^{2}$, and A. Pozzer ${ }^{1}$

${ }^{1}$ Atmospheric Chemistry Department, Max Planck Institute for Chemistry, Mainz, Germany

${ }^{2}$ Computation-based Science and Technology Research Center, The Cyprus Institute, Nicosia, Cyprus

Received: 15 October 2015 - Accepted: 9 November 2015 - Published: 24 November 2015

Correspondence to: S. Bacer (sara.bacer@mpic.de)

Published by Copernicus Publications on behalf of the European Geosciences Union.

Title Page

Abstract

Conclusions

Tables

14

4

Back

Introduction

References

Figures

$>1$

$>$

Close

Printer-friendly Version

Interactive Discussion

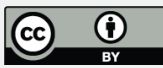




\section{Abstract}

The North Atlantic Oscillation (NAO) plays an important role in the climate variability of the Northern Hemisphere with significant consequences on pollutant transport. We study the influence of the NAO on the atmospheric dispersion of pollutants in the near 5 past and in the future by considering simulations performed by the ECHAM/MESSy Atmospheric Chemistry (EMAC) general circulation model. We analyze two model runs: a simulation with circulation dynamics nudged towards ERA-Interim reanalysis data over a period of 35 years (1979-2013) and a simulation with prescribed Sea Surface Temperature (SST) boundary conditions over 150 years (1950-2099). The model is with observations. We find that the decadal variability in the NAO, which has been pronounced since 1950s until 1990, will continue to dominate in the future considering decadal periods, although no significant trends are present in the long term projection (100-150 years horizon). We do not find in the model projections any significant tem15 poral trend of the NAO for the future, meaning that neither positive or negative phases will dominate. Tracers with idealised decay and emissions are considered to investigate the NAO effects on transport; it is shown that during the positive phase of the NAO, the transport from North America towards northern Europe is stronger and pollutants are shifted northwards over the Arctic and southwards over the Mediterranean and North Africa, with two distinct areas of removal and stagnation of pollutants.

\section{Introduction}

The North Atlantic Oscillation (NAO) is the most prominent recurrent pattern of atmospheric variability over middle and high latitudes in the Northern Hemisphere (NH). It refers to oscillations in the meridional atmospheric pressure difference between the sub-polar and sub-tropical North Atlantic Ocean which produce large changes in the mean wind speed and direction, heat and moisture transport, surface temperature and
ACPD

15, 33049-33075, 2015

NAO evolution and tracer transport

S. Bacer et al.

Title Page

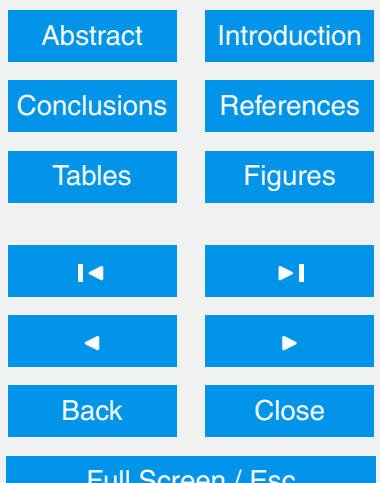

Full Screen / Esc

Printer-friendly Version

Interactive Discussion 
intensity of precipitation, especially during boreal winter (Hurrell et al., 2003, and references therein). The NAO influence on the mean winter climate across much of the $\mathrm{NH}$ is well established (Hurrell, 1995). When the polar low and tropical high surface pressures are relatively stronger, the pressure difference is higher than average (pos5 itive NAO phase) and the north-south pressure gradient produces surface westerlies stronger than average across the middle latitudes of the Atlantic towards northern Europe. In periods with the polar low and tropical high surface pressure relatively weaker (negative NAO phase) the flow has a reduced zonal component. Several studies (Hurrell, 1995; Visbeck et al., 2001; Hurrell et al., 2003) have linked the westerly flow during 10 positive NAO with warm and moist maritime air over northern-western Europe, accompanied with enhanced precipitation, and colder and drier conditions over the Mediterranean.

Since the NAO exerts strong influence on the boreal winter weather it can be also expected to influence pollutants transport on hemispheric scale. Several studies have investigated the relationship between the phases of NAO and pollutant transport. Moulin et al. (1997) studied the role of the NAO in controlling the desert dust transport into the Atlantic and Mediterranean and suggested that the NAO likely affects the distribution of anthropogenic aerosols. Li et al. (2002) found that there is an increase of North American ozone at Mace Head Ireland during positive NAO, when westerly winds across the North Atlantic are stronger. Creilson et al. (2003) also analyzed the relationship between the NAO phases and the tropospheric ozone transport across the North Atlantic and discovered that rises of ozone over western Europe are strongly correlated with positive NAO. Pausata et al. (2012) showed both with station measurements and coupled atmoshere-chemistry model simulations that the NAO affects surface ozone relationship between the NAO and the pollutant transport towards the Artic and found that concentrations of surface carbon monoxide, both from Europe and North America, increase in the Arctic during the NAO positive phase.

\section{ACPD}

15, 33049-33075, 2015

NAO evolution and tracer transport

S. Bacer et al.

Title Page

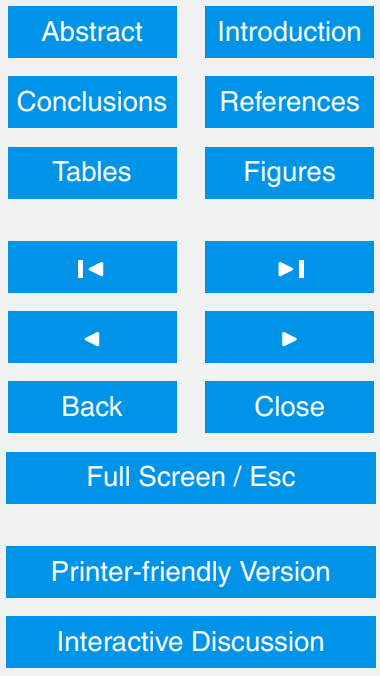

Interactive Discussion 
The study of export pathways of European pollution by Duncan et al. (2004) confirms that the carbon monoxide burden from European sources tends to be lower over the North Atlantic and higher over the Arctic in the same periods. Christoudias et al. (2012) studied the emissions and transport of tagged idealised tracers in the atmosphere in 5 relation to the NAO, confirming these findings. They also found that during high NAO the trace gases emitted from North are transported relatively far to the northern-eastern Europe and that trace gases emitted over Europe are transported mostly over Africa and northern Arctic Circle. The sensitivity study by Thomas et al. (2014) regarding the free tropospheric carbon monoxide concentrations to different atmospheric weather 10 states confirmed the NAO control in pollutant distribution and transport over the region of Nordic countries.

Finally, some recent works have linked the NAO with aerosol concentration variations. Jerez et al. (2013) investigated the NAO impact on the local atmospheric scale processes and the consequences on ground level aerosol concentrations over Europe. 15 They found that winds, precipitation and temperatures decrease (increase) aerosol concentrations over southern Europe during positive (negative) NAO. Pausata et al. (2015) analyzed the impacts of aerosol reduction (after air pollution mitigation strategies), in combination with greenhouse gases (GHGs) increment, on the winter North Atlantic atmospheric circulation. Their results showed an expectation for more positive NAO mean, together with an eastward shift of the southern centre of action of sea level pressure.

The aforementioned studies suggest that the knowledge of the future NAO phases can potentially be used to project and even forecast North American and European pollutant transport over Europe and the Arctic. However there are still open research questions about which climate processes could influence the future development of the $\mathrm{NAO}$ and its variability. Although the NAO is an intrinsic mode of atmospheric variability, surface (ocean and land), stratospheric, anthropogenic processes may influence its phase and amplitude, in ways that may be only in part predictable. At present there is no consensus on the process or processes that are responsible for the observed

\section{ACPD}

15, 33049-33075, 2015

NAO evolution and tracer transport

S. Bacer et al.

Title Page

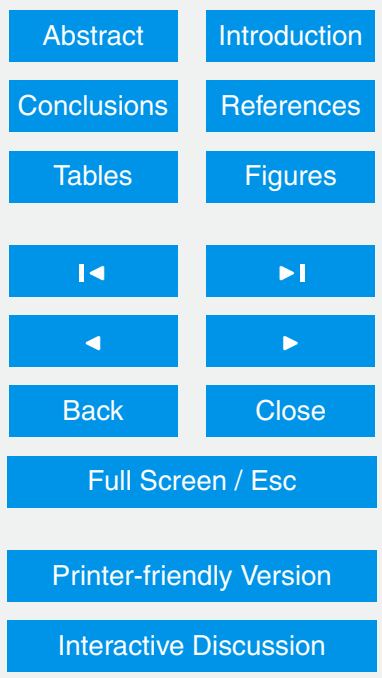


low-frequency variations in the NAO (Visbeck et al., 2001; Hurrell et al., 2003). Many studies have suggested some external forcing, like the increase of greenhouse gases (Kuzmina et al., 2005), the warmer tropical sea surface temperature (Hoerling et al., 2001) and the strengthened stratospheric vortex (Baldwin and Dunkerton, 2001), as 5 the causes of the upward NAO trend observed from 1960s until 1990s, which was projected to continue in the future (Visbeck et al., 2001; Gillett et al., 2003). These results were superseded by more recent studies (Scaife et al., 2007) showing that the upward trend has recently reversed downwards, suggesting that the previous positive trend was due to natural climate variability (and not external factors); if that is indeed future, leaving open questions about their origin and the predictability of the NAO.

In this paper we use a global climate circulation model to investigate the temporal variability of the NAO pattern, including multi-year to decadal trends from the recent past to the end of the century, and its relation to the spatial variability of atmospheric 15 pollutants. We consider two simulations generated by ECHAM/MESSy Atmospheric Chemistry (EMAC) climate model:

- simulation RC1SD-base-09 (1979-2013) nudged by applying a Newtonian relaxation (Jeuken et al., 1996) towards the European Centre for Medium-range Weather Forecast (ECMWF) ERA-Interim reanalysis data (Dee et al., 2011). Nudged variables are divergence and vorticity of the wind, temperature, and the logarithm of the surface pressure;

- simulation RC2-base-05 (1950-2099) driven by prescribed Sea Surface Temperature (SST) and Sea Ice Coverage (SIC) taken from simulations with the global climate model HadGEM2-ES (Collins et al., 2011; The HadGEM2 Development Team, 2011) for the Coupled Model Intercomparison Project phase 5 (CMIP5).

We analyze the NAO signal, the influence of the NAO on the pollutant transport over the North Atlantic sector and scan for significant trends in the future projections. In 33053

\section{ACPD}

15, 33049-33075, 2015

NAO evolution and tracer transport

S. Bacer et al.

Title Page

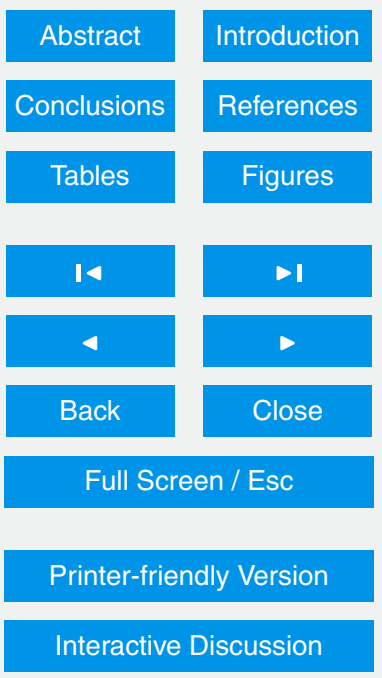

Interactive Discussion 
our analysis, we consider the carbon monoxide $\mathrm{CO}$ pollutant tracer, which is directly emitted by combustion sources and has a lifetime of 1-3 months in the atmosphere; thus it has a long atmospheric residence lifetime relative to the time scales of transport. Our analysis refers to the winter DJF (December-January-February) seasonal means 5 for the main features, as the sea level pressure (SLP) amplitude anomalies are larger in winter and the NAO is typically stronger in this period.

We briefly describe the model simulations and observations in Sect. 2, while the spatial structure and temporal evolution of the NAO, for both simulations, are presented in Sect. 3 along with the NAO trends. The analysis of the NAO influence on tracer 10 transport is discussed in Sect. 4 together with the future implications. Our conclusions are given in Sect. 5 .

\section{Methodology}

\subsection{Model simulations}

The ECHAM/MESSy Atmospheric Chemistry (EMAC) model is a numerical chemistry 15

and climate simulation system that includes sub-models describing tropospheric and middle atmosphere processes and their interaction with oceans, land and human influences (Jöckel et al., 2015). It uses the second version of the Modular Earth Submodel System (MESSy2) to link multi-institutional computer codes. The core atmospheric model is the 5th generation European Centre Hamburg general circulation model (ECHAM5, Roeckner et al., 2006).

For the present study we used ECHAM5 version 5.3.02 and MESSy version 2.51; more specifically we used simulations RC2-base-05 and RC1SD-base-09 from the ESCiMo project (Jöckel et al., 2015). Table 1 summarizes the main characteristics of the simulations; a detailed description can be found in Jöckel et al. (2015) and references. Both simulations used T42L47MA-resolution, i.e. with a spherical truncation of T42 (corresponding to a quadratic Gaussian grid of approx. $2.8^{\circ}$ by $2.8^{\circ}$ in latitude

\section{ACPD}

15, 33049-33075, 2015

NAO evolution and tracer transport

S. Bacer et al.

Title Page
Abstract

Conclusions

Tables

14

4

Back
Introduction

References

Figures

$>1$

$>$

Close
Full Screen / Esc

Printer-friendly Version

Interactive Discussion 
and longitude) and 47 vertical hybrid pressure levels up to $0.01 \mathrm{hPa}$. For this work, the CO tracer was used, emitted by transient anthropogenic sources (Fujino et al., 2006) with online calculated chemical decomposition. Two additional tracers named $\mathrm{CO}_{25}$ and $\mathrm{CO}_{50}$, included in the model simulations were used, with emissions modeled after 5 the $\mathrm{CO}$ for the year 2000 (i.e. no interannual variability) and with a constant exponential decay, with a e-folding time equal to 25 and 50 days, respectively. These tracers are well-suited for investigating transport related effects, as no chemical influences are present.

Simulation RC1SD-base-09 is used to model the recent past (hindcast of the years 10 1979-2013), while simulation RC2-base-05 is used to project the future development of the climate (up to the year 2099).

\subsection{Observations}

Two kinds of NAO temporal indices produced by the Climate Analysis Section of the National Center for Atmospheric Research (NCAR) were used to diagnose the NAO signal simulated by the model. The "station-based NAO index" (Hurrell and NCAR, 1995) is based on measurements of the SLP and is available since 1865. The "PC-based NAO index" (Hurrell and NCAR, 2003) is obtained from the Principal Component time series of the leading Empirical Orthogonal Function of the NCAR Sea Leve Pressure dataset since 1899.

20 Surface observations of CO were obtained from the World Data Centre for Greenhouse Gases (WDCGG), established by the World Meteorological Organization Global Atmosphere Watch (WMO, 2015). The goal of the WDCGG is to assist in more reliable monitoring and analyzing of greenhouse $\left(\mathrm{CO}_{2}, \mathrm{CH}_{4}, \mathrm{CFCs}, \mathrm{N}_{2} \mathrm{O}\right.$, etc. $)$ and related gases $\left(\mathrm{CO}, \mathrm{NO}_{x}, \mathrm{SO}_{2}\right.$, volatile organic compounds, etc.). In this work only sta25 tions located in the North East America, North Atlantic and North Europe were used. Station locations and contributors are listed in the Supplement.

\section{ACPD}

15, 33049-33075, 2015

NAO evolution and tracer transport

S. Bacer et al.

Title Page

Abstract

Introduction

Conclusions

References

Tables

Figures

14

$>1$

4

Back

Close

Full Screen / Esc

Printer-friendly Version

Interactive Discussion 


\section{NAO representations and trends}

\subsection{NAO evaluation}

In order to define the spatial structure and temporal evolution of the NAO we use Empirical Orthogonal Function analysis (EOF). This approach consists in computing the 5 eigenvectors of the cross-covariance matrix of the time variations of the SLP (Hurrell et al., 2003). By definition, the eigenvectors are spatially and temporally mutually orthogonal and scale according to the amount of the total variance they explain. The leading EOF (EOF1) explains the largest percentage of the temporal variance in the dataset. The NAO is identified by the EOFs of the cross-covariance matrix calculated from seasonal (3months average) SLP anomalies in the North Atlantic sector (20$\left.80^{\circ} \mathrm{N}, 90^{\circ} \mathrm{W}-40^{\circ} \mathrm{E}\right)$. The EOF1 spatial pattern is always associated with a north-south pressure dipole and its centers of action coincide with the NAO poles of highest SLP variability.

In our study the EOF analysis for the winter season (DJF) shows that the nudged simulation RC1SD-base-09 well captures the NAO signal: the leading EOF (Fig. 1, top) explains $53.0 \%$ of the total variance and the pattern has the typical dipolar structure, while the second EOF (Fig. 1, bottom) represents $14.6 \%$ of the total variance. The patterns are displayed in terms of amplitude $(\mathrm{hPa})$ obtained by regressing the SLP anomalies upon the leading principal component time series; we can observe maximum departures of the field of order of $\pm 3 \mathrm{hPa}$ at the central poles.

The first two spatial EOFs computed also for the long simulation RC2-base-05 are shown in Fig. 2. The percentages of the total variance explained are $36.2 \%$ for EOF1 and $19.1 \%$ for EOF2. Both patterns, displayed in terms of amplitude (hPa), are comparable with the spatial structure of the NAO and the variability pattern for the North Atlantic: a dipole in EOF1 and a monopole in EOF2. This indicates that the model with the prescribed SSTs reproduces the characteristic signature of the NAO in a realistic fashion.

NAO evolution and tracer transport

S. Bacer et al.

Title Page
Abstract

Conclusions

Tables

14

4

Back
Introduction

References

Figures

$>$ I

>

Close
Full Screen / Esc

Printer-friendly Version

Interactive Discussion 
NAO indices (NAOI) for the description of the NAO temporal evolution are derived from the SLP difference between two locations (NAOl-press) or from the time series of the leading EOF of SLP (EOF1-ts) (Hurrell et al., 2003). NAOl-press is based on the difference of normalized sea level pressure between one northern and one southern 5 station. We will mostly consider only EOF-ts in the following analysis. However, as the two NAOIs are highly correlated especially so in the winter season, with a correlation coefficient $\left(R^{2}\right)$ of 0.92 for the case of the nudged simulation RC1SD-base-09 (Fig. 3), it is reasonable to interchange them to diagnose the temporal variation of the NAO pattern. The same is valid for the long simulation: the NAO-press and EOF1-ts from 10 simulation RC2-base-05 correlate highly $\left(R^{2}=0.88\right)$ for the period 1979-2013 (Fig. 3) and also for the entire simulation $\left(1950-2099\right.$, with $\left.R^{2}=0.84\right)$. A $t$ test between simulations RC1SD-base-09 and RC2-base-05 for the calculated NAOI showed that both simulations are compatible with stemming from the same distribution with equivalent variance.

15 In order to validate the model capacity in reproducing the NAO we compared the modeled NAOI-press, computed between the stations Ponta Delgada-Azores $\left(37.7^{\circ} \mathrm{N}\right.$; $\left.25.7^{\circ} \mathrm{W}\right)$ and Stykkisholmur/Reykjavik-Iceland $\left(65.1^{\circ} \mathrm{N} ; 22.7^{\circ} \mathrm{W}\right)$ for DJF of the nudged simulation, with the observed NAOI-press (Hurrell and NCAR, 1995). The correlation coefficient between these two NAOI is equal to 0.99 (Fig. 3), signifying that the nudged

\subsection{NAO projection trends}

To investigate the NAO temporal variability and trends over the simulated period, we estimated the linear regression coefficients of the principal component time series of the EOF1 in sliding windows with variable lengths. We considered windows variable 25 in length between a minimum of 10 years and maximum equal to the simulated period and sliding along the whole time series; we computed the linear trend for each case and assigned the slope value to the central year of the window, e.g. the regression coefficient of the period 1979-1989 (11 years window) was assigned to the year 1984 . 33057

\section{ACPD}

15, 33049-33075, 2015

NAO evolution and tracer transport

S. Bacer et al.

Title Page

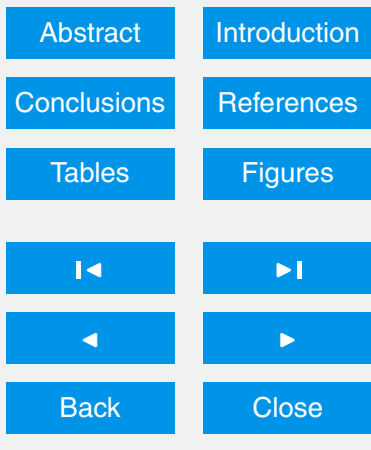

Full Screen / Esc

Printer-friendly Version

Interactive Discussion 
Figure 4 (top) shows trends of EOF1-ts of the nudged simulation computed following this method. Plotted in the horizontal axis are the window lengths expressed in years and in the vertical axis the central years of the windows. The color bar indicates the slope magnitudes (expressed in $\mathrm{hPayear}^{-1}$ ). Trends with statistical significance at the $590 \%$ level or above are marked with black crosses. Similarly, in Fig. 4 (center) we considered the NAO principal component (PC-ts) based index (Hurrell and NCAR, 2003) for the same period as the nudged simulation (1979-2013). The patterns and values of the two plots are similar confirming the capability of the model (and simulation RC1SDbase-09 in particular) in reproducing results comparable to the observations. There are 10 two clear patterns in the plots: an upward trend (red shading) which dominates between 1984 and 1991 and a downward trend (blue shading) which dominates during almost all periods from 1992 onwards, considering decadal time-scales. The positive trend in the first period is confirmed by other studies (Visbeck et al., 2001; Gillett et al., 2003); nevertheless, on a longer 35 years horizon (1979-2013), the trend is non-significant.

For the analysis of past and future trends we applied the method described before to the longer RC2-base-05 simulation. Firstly we computed the regression coefficients considering the same temporal period of the nudged simulation (1979-2013): the slope values, shown in Fig. 4 (bottom), are very similar to the nudged simulation ones (Fig. 4 top and middle). This indicates that the SSTs have a significant impact on the NAO evolution, as it has been already demonstrated in the past: the low-frequency North Atlantic climate variability is not only a stochastic atmospheric noise, but it is also influenced by the ocean surface temperature (Hurrell et al., 2001). However, while the response of the Atlantic Ocean to changes in the NAO is firmly established, the strength of the feedback of the SSTs variations on the atmospheric state is yet to be quantified (Visbeck et al., 2003; Czaja et al., 2003).

The trend analysis for the whole period of the long simulation is shown in Fig. 5. The area inside the green triangle corresponds to Fig. 4 (bottom). No change in the projected future NAO variability is noticeable compared to the recent past, when considering periods shorter than 30 years. Considering windows of length between 30 and

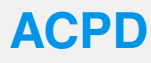

15, 33049-33075, 2015

NAO evolution and tracer transport

S. Bacer et al.

Title Page

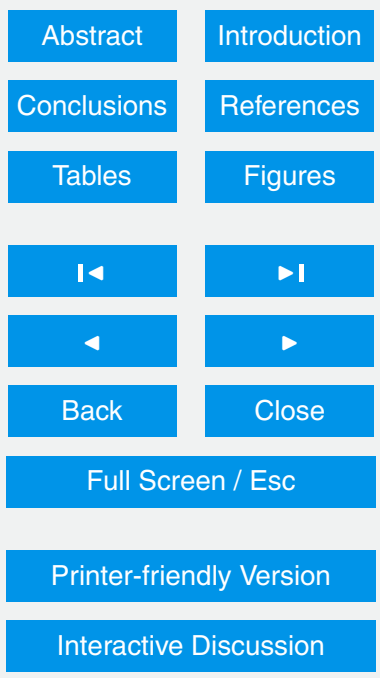


60 years, downward trends (centred in the 1980s and 2040s) interchange with upward trends (centred in the 2010s and 2060s). When considering longer window lengths, we find two main tendencies: downward trends in the first part of the simulation and upward ones in the second part of the simulation (with an evident significant area) compatible with zero, but no long term trend in the NAO pattern projected by our model.

We can conclude that the decadal variability in NAO, which has been pronounced since 1950s until 1990 (Hurrell, 1995), will continue to dominate in the future considering decadal periods, although no significant trends are present in the long term projection (100-150 years horizon) based on our model simulations. To further check 10 these findings, the full IGAC/SPARC Chemistry-Climate Model Initiative (CCMI, 2013) model ensemble will be intercompared once finalized and available.

\section{NAO effects on tracer transport}

Using the nudged simulation, we computed the correlation between the principal component time series of the leading EOF and tracer mixing ratios at surface level. In this analysis the $\mathrm{CO}$ was used, as it has a relative moderate lifetime (1-2 months) comparable to intercontinental transport time scales and additionally can be used as proxy for anthropogenic pollutions, as it is mostly emitted by biomass burning and human activities (Pozzer et al., 2007).

In Fig. 6 (top) the EOF1-ts and CO mixing ratio computed at the surface level are 20 significantly correlated over East American coast, Canada, North Africa, the Mediterranean and above the Arctic Circle. They are anti-correlated over northern Europe and the tropical Atlantic Ocean, but not statistically significant. The areas with correlation at the surface level are linked to the main features of the positive NAO phase, when stronger-than-average surface westerlies are oriented towards northern Europe, with the Canadian Arctic and the Mediterranean (Hurrell et al., 2003). In this regime, with a stronger separation of the flow over Europe, the European tracers are relatively de-

\section{ACPD}

15, 33049-33075, 2015

NAO evolution and tracer transport

S. Bacer et al.

Title Page
Abstract

Conclusions

Tables

14

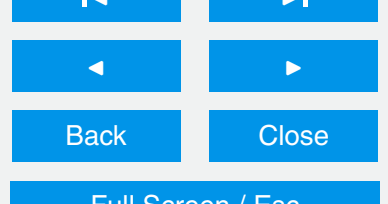

Full Screen / Esc

Printer-friendly Version
Interactive Discussion

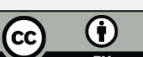


pleted over northern Europe and relatively higher concentrations are shifted towards southern Europe, northern Africa and the Arctic. On the other hand air pollution concentrations are lower over northern Europe during the negative phase of the NAO, when the westerlies are weaker and clean Arctic air is transported southwards. Our re5 sults agree with the findings of Christoudias et al. (2012), who examined the influence of the NAO on the atmospheric dispersion of pollutant tracers tagged by the continent of origin for a period of 50 years (1960-2010). Christoudias et al. (2012) computed a similar correlation considering $\mathrm{CO}$ emitted in Europe and in North America. Such a comparison is justified by the fact that most of $\mathrm{CO}$ in Europe is influenced by emis10 sions from Europe and partially from North America, while the contribution from Asian emissions is smaller (Duncan et al., 2008).

To evaluate our modeled results we computed the correlation between the winter seasonal means (DJF) of CO mixing ratio measurements (WMO, 2015), collected in the stations indicated with green circles in Fig. 6 (top), and the PC-ts index by Hurrell and NCAR (1995). The results are shown in Fig. 6 (bottom). Observation records begin in January 1979 and end in 2015. We only considered stations having at least 8 winter seasonal means and, for each of them, we selected the longest temporal series when more series were available at the same station. Following these criteria we obtained the correlations shown in Fig. 6 (bottom). The station point data are in agreement with the pattern obtained with the modeled values (Fig. 6, top), with singular discrepancies in the western Atlantic Ocean, in Ireland, in the North Sea and Baltic Sea. Observations show a strong negative correlation in Central Europe, where there is a transition zone between positive and negative values in Fig. 6 (top). In all cases the results based on observations are always computed with a smaller sample size than the number of 25 years of the nudged simulation (35 years).

For the nudged simulation we also computed the correlation between the EOF1-ts and the mixing ratio of $\mathrm{CO}$ with e-folding time equal to 25 days $\left(\mathrm{CO}_{25}\right.$, see Sect. 2.1) at the surface level (Fig. 7, top). In this case the correlations represent purely the tracer transport, since emissions and the decay lifetime are constant in time and there is no

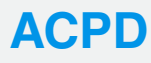

15, 33049-33075, 2015

NAO evolution and tracer transport

S. Bacer et al.

Title Page

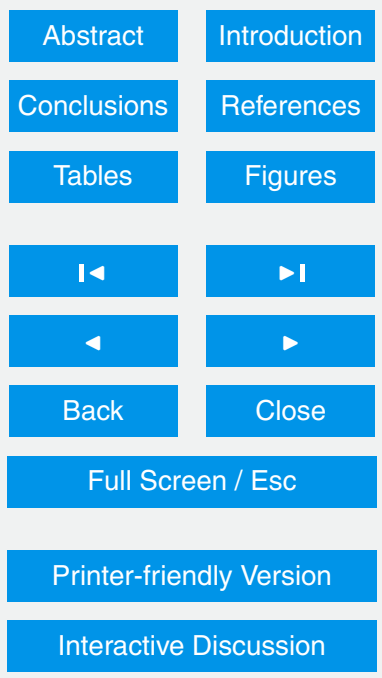

Interactive Discussion 
influence by chemical production/decomposition variability. At the surface, a large significant anti-correlated area extends over the Atlantic Ocean, northern-eastern Europe and Greenland while there is a strong significant correlation over northern-western Africa, Iberian Peninsula, Arctic Circle and North America. The anti-correlated area is 5 greater in extent than the one for the $\mathrm{CO}$ (Fig. 6, top) showing the same direction towards North-East but also a new area over Greenland, making a tripole-shape. The analysis taking into account $\mathrm{CO}_{50}$ (e-folding time of 50 days) leads to similar results (see the Supplement).

\section{Future implications}

10 The analysis of the tracer transport was repeated for the long simulation (RC2-base05). In Fig. 7 (bottom), correlations for $\mathrm{CO}_{25}$ at the surface are shown. Comparing to the equivalent results of the nudged simulation, the correlated areas increase in span from Africa towards the Atlantic Ocean and decrease over North America, while the anti-correlated ones are of lower magnitude. The patterns of both simulations exhibit 5 strong similarities, as the contours and significant areas show little differences and the tripole-spatial distribution is still present. These results suggest that during positive NAO events there is and will be a strong dichotomy regarding the influence on air quality and pollution over Europe. In particular, the positive NAO phase can contribute to make South Europe suffering from more stagnation and higher pollutant local concentration while North Europe benefits from a higher air quality. Also in this case, the analysis considering $\mathrm{CO}_{50}$ has produced similar results (see the Supplement) signifying robustness of the conclusion over the uncertainties associated with pollutant tracers atmospheric residence lifetimes.

\section{ACPD}

15, 33049-33075, 2015

NAO evolution and tracer transport

\section{S. Bacer et al.}

Title Page

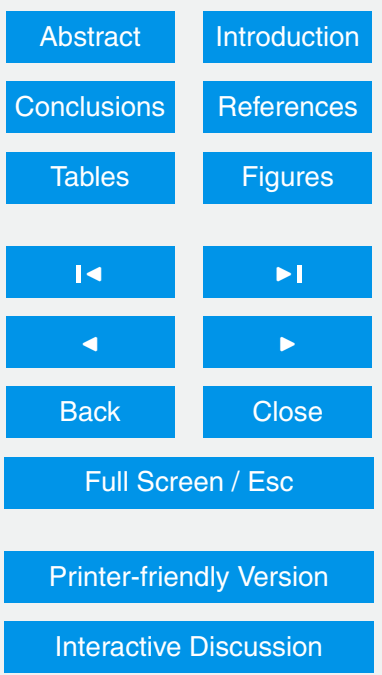




\section{Conclusions}

Two simulations of the ESCiMo project (Jöckel et al., 2015, RC1SD-base-09 and RC2base-05) performed with the EMAC model were analyzed in order to study the NAO evolution and influence on pollutant transport.

The model is able to well reproduce the SLP anomalies and the NAO signal. Indeed the spatial analysis of both simulations shows the typical dipolar structure which identifies the NAO phenomenon. Moreover the NAO temporal index computed for the nudged simulation is highly correlated with observations.

By analyzing the trends in the nudged simulation a clear downward tendency of the 10 NAO (considering the period after 90s) is apparent, in agreement with other recent studies. However, when considering the variability of the NAO projection, we can infer that there is no significant trend expected in the future. Our results indicate that the $\mathrm{NAO}$ is influenced by natural climate variability rather than external factors. We find confirmation that SSTs influence the NAO evolution.

15 The final aim of this work was the study of the NAO influence on the tracer transport, by examining its correlation with tracer mixing ratios. During the positive NAO phases, when stronger than average westerlies cross the middle latitudes of the Atlantic, the purely dynamics-influenced tracer $\mathrm{CO}_{25}$ is advected from North America towards Europe reaching the Arctic zone, the southern Mediterranean and North Africa.

20 The transport of $\mathrm{CO}$, also influenced by chemistry, is less significant, nevertheless the observations mostly confirm our model results. Moreover the CO-correlation for the nudged simulation also shows a tripole-distribution like the pattern obtained for the idealised case of the $\mathrm{CO}_{25}$.

Since the NAO is strongly correlated with pollutant transport, the NAO Indices may 25 be used as indicators of (future) pollutant transport over Europe. Our results indicate no expectation for a significant trend of the NAO in this century and that strong NAO events generally imply a splitting over Europe between the northern part with influence

\section{ACPD}

15, 33049-33075, 2015

NAO evolution and tracer transport

S. Bacer et al.

Title Page

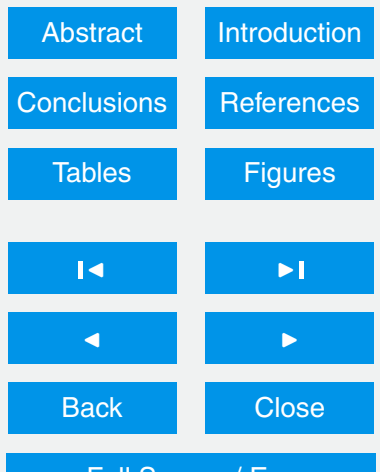

Full Screen / Esc

Printer-friendly Version

Interactive Discussion 
leading to lower pollution concentrations and the southern part with air stagnation of pollutants.

\section{The Supplement related to this article is available online at doi:10.5194/acpd-15-33049-2015-supplement.}

5 Acknowledgements. The authors wish to extend their gratitude to the MESSy Consortium and the international IGAC/SPARC Chemistry-Climate Model Initiative (CCMI, 2013). The simulations analysed here were carried out as part of the Earth System Chemistry integrated Modelling (ESCiMo) project at the German Climate Computing Centre (Deutsches Klimarechenzentrum, DKRZ). DKRZ and its scientific steering committee are gratefully

The article processing charges for this open-access publication were covered by the Max Planck Society.

\section{References}

Baldwin, M. P. and Dunkerton, T. J.: Stratospheric harbingers of anomalous weather regimes, Science, 294, 581-584, 2001. 33053

Christoudias, T., Pozzer, A., and Lelieveld, J.: Influence of the North Atlantic Oscillation on air pollution transport, Atmos. Chem. Phys., 12, 869-877, doi:10.5194/acp-12-869-2012, 2012. 33052, 33060

Collins, W. J., Bellouin, N., Doutriaux-Boucher, M., Gedney, N., Halloran, P., Hinton, T., Hughes, J., Jones, C. D., Joshi, M., Liddicoat, S., Martin, G., O'Connor, F., Rae, J., Senior, C., Sitch, S., Totterdell, I., Wiltshire, A., and Woodward, S.: Development and evaluation of an Earth-System model - HadGEM2, Geosci. Model Dev., 4, 1051-1075, doi:10.5194/gmd-41051-2011, 2011. 33053

Creilson, J. K., Fishman, J., and Wozniak, A. E.: Intercontinental transport of tropospheric ozone: a study of its seasonal variability across the North Atlantic utilizing tropospheric ozone

NAO evolution and tracer transport

S. Bacer et al.

\section{Title Page}

Abstract

Conclusions

Tables

14

4

Back

Printer-friendly Version

Interactive Discussion
$>1$

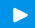

Close

\section{Full Screen / Esc}

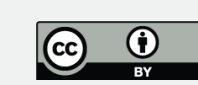


residuals and its relationship to the North Atlantic Oscillation, Atmos. Chem. Phys., 3, 20532066, doi:10.5194/acp-3-2053-2003, 2003. 33051

Czaja, A., Robertson, A. W., and Huck, T.: The role of Atlantic ocean-atmosphere coupling in affecting North Atlantic Oscillation variability, in: The North Atlantic Oscillation: Climatic Significance and Environmental Impact, edited by: Hurrell, J. W., Kushnir, Y., Ottersen, G., and Visbeck, M., Geophysical Monograph Series, 134, American Geophysical Union, Washington, DC, USA, 147-172, 2003. 33058

Dee, D. P., Uppala, S. M., Simmons, A. J., Berrisford, P., Poli, P., Kobayashi, S., Andrae, U., Balmaseda, M. A., Balsamo, G., Bauer, P., Bechtold, P., Beljaars, A. C. M., van de Berg, L., Bidlot, J., Bormann, N., Delsol, C., Dragani, R., Fuentes, M., Geer, A. J., Haimberger, L., Healy, S. B., Hersbach, H., Hólm, E. V., Isaksen, L., Kallberg, P., Köhler, M., Matricardi, M., McNally, A. P., Monge-Sanz, B. M., Morcrette, J.-J., Park, B.-K., Peubey, C., de Rosnay, P., Tavolato, C., Thépaut, J.-N., and Vitart, F.: The ERA-Interim reanalysis: configuration and performance of the data assimilation system, Q. J. Roy. Meteor. Soc., 137, 553-597, doi:10.1002/qj.828, 2011. 33053

Duncan, B. N. and Bey, I.: A modeling study of the export pathways of pollution from Europe: seasonal and interannual variations (1987-1997), J. Geophys. Res., 109, D08301, doi:10.1029/2003JD004079, 2004. 33052

Duncan, B. N. and Logan, J. A.: Model analysis of the factors regulating the trends and variability of carbon monoxide between 1988 and 1997, Atmos. Chem. Phys., 8, 7389-7403, doi:10.5194/acp-8-7389-2008, 2008. 33060

Eckhardt, S., Stohl, A., Beirle, S., Spichtinger, N., James, P., Forster, C., Junker, C., Wagner, T., Platt, U., and Jennings, S. G.: The North Atlantic Oscillation controls air pollution transport to the Arctic, Atmos. Chem. Phys., 3, 1769-1778, doi:10.5194/acp-3-1769-2003, 2003. 33051

Eyring, V., Lamarque, J. F., Hess, P., Arfeuille, F., Bowman, K., Chipperfield, M. P., Duncan, B., Fiore, A., Gettelman, A., Giorgetta, M. A., Granier, C., Hegglin, M., Kinnison, D., Kunze, M., Langematz, U., Luo, B., Martin, R., Matthes, K., Newman, P. A., Peter, T., Robock, A., Ryerson, T., Saiz-Lopez, A., Salawitch, R., Schultz, M., Shepherd, T. G., Shindell, D., Staehelin, J., Tegtmeier, S., Thomason, L., Tilmes, S., Vernier, J.-P., Waugh, D. W., and Young, P. J.: tions in support of upcoming ozone and climate assessments, SPARC Newsletter, 40,48-66, 2013. 33059, 33063

\section{ACPD}

15, 33049-33075, 2015

NAO evolution and tracer transport

S. Bacer et al.

\section{Title Page}

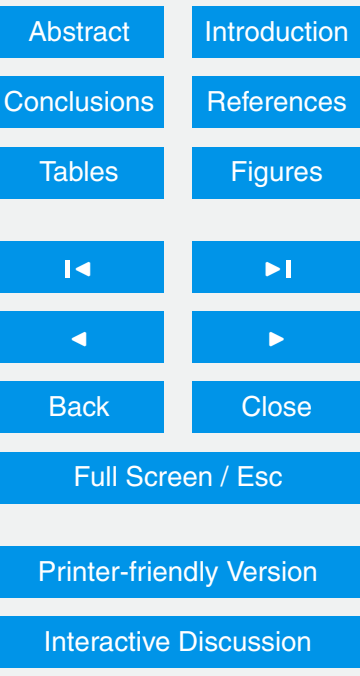


Fujino, J., Nair, R., Kainuma, M., Masui, T., and Matsuoka, Y.: Multi-gas mitigation analysis on stabilization scenarios using aim global model, Energy J., 27, 343-354, 2006. 33055

Gillett, N. P., Graf, H. F., and Osborn, T. J.: Climate change and the North Atlantic Oscilation, in: The North Atlantic Oscillation: Climatic Significance and Environmental Impact, edited by:

5 Hurrell, J. W., Kushnir, Y., Ottersen, G., and Visbeck, M., Geophysical Monograph Series, 134, American Geophysical Union, Washington, DC, USA, 193-209, 2003. 33053, 33058

Hoerling, M. P., Hurrell, J. W., and Xu, T.: Tropical origins for the recent North Atlantic climate change, Science, 292, 90-92, doi:10.1126/science.1058582, 2001. 33053

Hurrell, J. W.: Decadal trends in the North Atlantic Oscillation: regional temperatures and precipitation, Science, 269, 676-679, 1995. 33051, 33059

Hurrell, J. W. and NCAR (National Center for Atmospheric Research Staff): The Climate Data Guide: hurrell North Atlantic Oscillation Index, station-based, available at: https://climatedataguide.ucar.edu/climate-data/ hurrell-north-atlantic-oscillation-nao-index-station-based (last access: 30 March 2015), 1995. 33055, 33057, 33060

Hurrell, J. W. and NCAR (National Center for Atmospheric Research Staff): The Climate Data Guide: hurrell North Atlantic Oscillation Index, PC-based, available at: https://climatedataguide.ucar.edu/climate-data/ hurrell-north-atlantic-oscillation-nao-index-pc-based (last access: 30 March 2015), 2003. 33055, 33058

Hurrell, J. W., Kushnir, Y., and Visbeck, M.: The North Atlantic Oscillation, Science, 291, 603605, 2001. 33058

Hurrell, J. W., Kushnir, Y., Ottersen, G., and Visbeck, M.: An overview of the North Atlantic Oscillation, in: The North Atlantic Oscillation: Climatic Significance and Environmental Impact, edited by: Hurrell, J. W., Kushnir, Y., Ottersen, G., and Visbeck, M., Geophysical Monograph Series, 134, American Geophysical Union, Washington, DC, USA, 1-35, 2003. 33051, 33053, 33056, 33057, 33059

Jerez, S., Jimenez-Guerrero, P., Montávez, J. P., and Trigo, R. M.: Impact of the North Atlantic Oscillation on European aerosol ground levels through local processes: a seasonal model-
ACPD

15, 33049-33075, 2015

NAO evolution and tracer transport

S. Bacer et al.

Title Page

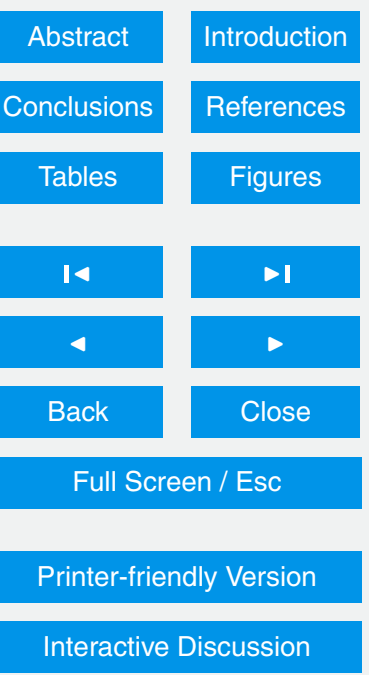


Jeuken, A. B. M., Siegmund, P. C., Heijboer, L. C., Feicher, J., and Bengtsson, L.: On the potential of assimilating meteorological anayses in a global climate model for the purpose of the model validation, J. Geophys. Res., 101, 16939-16950, 1996. 33053

Jöckel, P., Tost, H., Pozzer, A., Kunze, M., Kirner, O., Brenninkmeijer, C. A. M., Brinkop, S., $5 \quad$ Cai, D. S., Dyroff, C., Eckstein, J., Frank, F., Garny, H., Gottschaldt, K.-D., Graf, P., Grewe, V., Kerkweg, A., Kern, B., Matthes, S., Mertens, M., Meul, S., Neumaier, M., Nützel, M., Oberländer-Hayn, S., Ruhnke, R., Runde, T., Sander, R., Scharffe, D., and Zahn, A.: Earth System Chemistry Integrated Modelling (ESCiMo) with the Modular Earth Submodel System (MESSy, version 2.51), Geosci. Model Dev. Discuss., 8, 8635-8750, doi:10.5194/gmdd-88635-2015, 2015. 33054, 33062

Kuzmina, S. I., Bengtsson, L., Johannessen, O. M., Drange, H., Bobylev, L. P., and Miles, M. W.: The North Atlantic Oscillation and greenhouse-gas forcing, Geophys. Res. Lett., 32, L04703, doi:10.1029/2004GL021064, 2005. 33053

Li, Q., Jacob, D. J., Bey, I., Palmer, P. I., Duncan, B. N., Field, B. D., Martin, R. V., Fiore, A. M., 15 Yantosca, R. M., Parrish, D. D., Simmonds, P. G., and Oltmans, S. J.: Transatlantic transport of pollution and its effects on surface ozone in Europe and North America, J. Geophys. Res., 107, ACH4.1-ACH4.21, doi:10.1029/2001JD001422, 2002. 33051

Moulin, C., Lambert, C. E., Dulac, F., and Dayan, U.: Control of atmospheric export of dust from North Africa by the North Atlantic Oscillation, Nature, 387, 691-694, 1997. 33051

20 Pausata, F. S. R., Pozzoli, L., Vignati, E., and Dentener, F. J.: North Atlantic Oscillation and tropospheric ozone variability in Europe: model analysis and measurements intercomparison, Atmos. Chem. Phys., 12, 6357-6376, doi:10.5194/acp-12-6357-2012, 2012. 33051

Pausata, F. S. R., Gaetani, M., Messori, G., Kloster, S., and Dentener, F. J.: The role of aerosol in altering North Atlantic atmospheric circulation in winter and its impact on air quality, Atmos. Chem. Phys., 15, 1725-1743, doi:10.5194/acp-15-1725-2015, 2015. 33052

Pozzer, A., Jöckel, P., Tost, H., Sander, R., Ganzeveld, L., Kerkweg, A., and Lelieveld, J.: Simulating organic species with the global atmospheric chemistry general circulation model ECHAM5/MESSy1: a comparison of model results with observations, Atmos. Chem. Phys., 7, 2527-2550, doi:10.5194/acp-7-2527-2007, 2007. 33059

30 Roeckner, E., Brokopf, R., Esch, M., Giorgetta, M., Hagemann, S., Kornblueh, L., Manzini, E., Schlese, U., and Schulzweida, U.: Sensitivity of simulated climate to horizontal and vertical resolution in the ECHAM5 atmosphere model, J. Climate, 19, 3771-3791, 2006. 33054

\section{ACPD}

15, 33049-33075, 2015

NAO evolution and tracer transport

S. Bacer et al.

Title Page

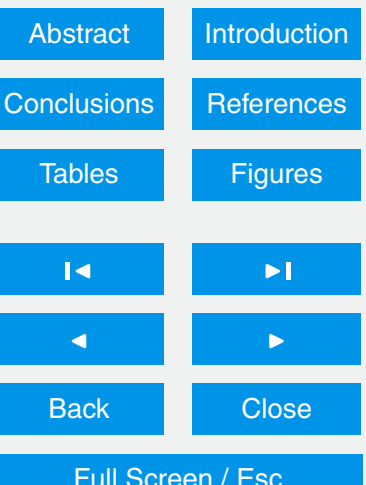

Full Screen / Esc

Printer-friendly Version

Interactive Discussion 
Scaife, A. A. and Folland, C. K.: European climate extremes and the North Atlantic Oscillation, J. Climate, 21, 72-82, doi:10.1175/2007JCLI1631.1, 2007. 33053

The HadGEM2 Development Team: Martin, G. M., Bellouin, N., Collins, W. J., Culverwell, I. D., Halloran, P. R., Hardiman, S. C., Hinton, T. J., Jones, C. D., McDonald, R. E., McLaren, A. J., O'Connor, F. M., Roberts, M. J., Rodriguez, J. M., Woodward, S., Best, M. J., Brooks, M. E., Brown, A. R., Butchart, N., Dearden, C., Derbyshire, S. H., Dharssi, I., Doutriaux-Boucher, M., Edwards, J. M., Falloon, P. D., Gedney, N., Gray, L. J., Hewitt, H. T., Hobson, M., Huddleston, M. R., Hughes, J., Ineson, S., Ingram, W. J., James, P. M., Johns, T. C., Johnson, C. E., Jones, A., Jones, C. P., Joshi, M. M., Keen, A. B., Liddicoat, S., Lock, A. P., Maidens, A. V., Manners, J. C., Milton, S. F., Rae, J. G. L., Ridley, J. K., Sellar, A., Senior, C. A., Totterdell, I. J., Verhoef, A., Vidale, P. L., and Wiltshire, A.: The HadGEM2 family of Met Office Unified Model climate configurations, Geosci. Model Dev., 4, 723-757, doi:10.5194/gmd-4-723-2011, 2011. 33053

Thomas, M. A. and Devasthale, A.: Sensitivity of free tropospheric carbon monoxide to atmospheric weather states and their persistency: an observational assessment over the Nordic countries, Atmos. Chem. Phys., 14, 11545-11555, doi:10.5194/acp-14-11545-2014, 2014. 33052

Visbeck, M., Chassignet, E. P., Curry, R. G., Delworth, T. L., Dickson, R. R., and Krahmann, G.: The ocean's response to North Atlantic Oscillation variability, in: The North Atlantic Oscillation: Climatic Significance and Environmental Impact, edited by: Hurrell, J. W., Kushnir, Y., Ottersen, G., and Visbeck, M., Geophysical Monograph Series, 134, American Geophysical Union, Washington, DC, USA, 113-145, 2003. 33058

Visbeck, M. H., Hurrell, J. W., Polvani, L., and Cullen, H. M.: The North Atlantic Oscillation: past, present, and future, P. Natl. Acad. Sci. USA, 98, 12876-12877, doi:10.1073/pnas.231391598, 2001. 33051, 33053, 33058

WMO (World Meteorological Organization): Global Atmospheric Watch stations network and other measurement, available at: http://www.wmo.int/pages/prog/arep/gaw/gaw_home_en. html, last access: 11 June 2015. 33055, 33060

\section{ACPD}

15, 33049-33075, 2015

NAO evolution and tracer transport

S. Bacer et al.

\section{Title Page}

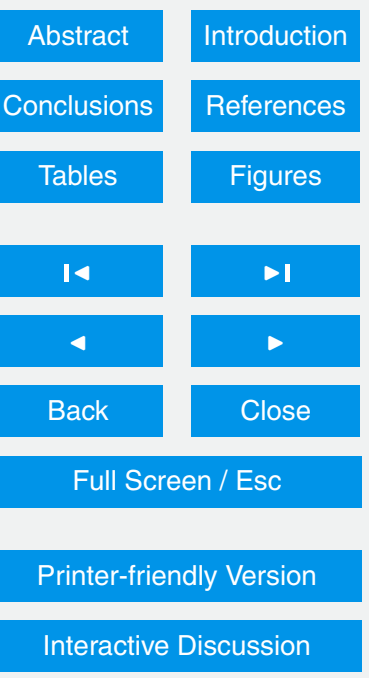


Table 1. Main characteristics of the numerical simulations used in our study.

\begin{tabular}{lllll}
\hline Name & Period & Years & Type & Resolution \\
\hline RC1SD-base-09 & $1979-2013$ & 35 & T42L47MA & $\begin{array}{l}\text { Nudged towards ERA-Interim } \\
\text { Re-analysis dynamics }\end{array}$ \\
RC2-base-05 & $1950-2099$ & 150 & T42L47MA & $\begin{array}{l}\text { Prescribed sea surface temper- } \\
\text { ature boundary conditions }\end{array}$ \\
\hline
\end{tabular}

ACPD

15, 33049-33075, 2015

NAO evolution and tracer transport

S. Bacer et al.

Title Page

Abstract

Introduction

Conclusions

References

Tables

Figures

14

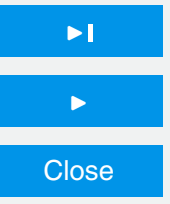

Back

Full Screen / Esc

Printer-friendly Version

Interactive Discussion 


\section{EOF 1}

SLP 1979-2013 DJF

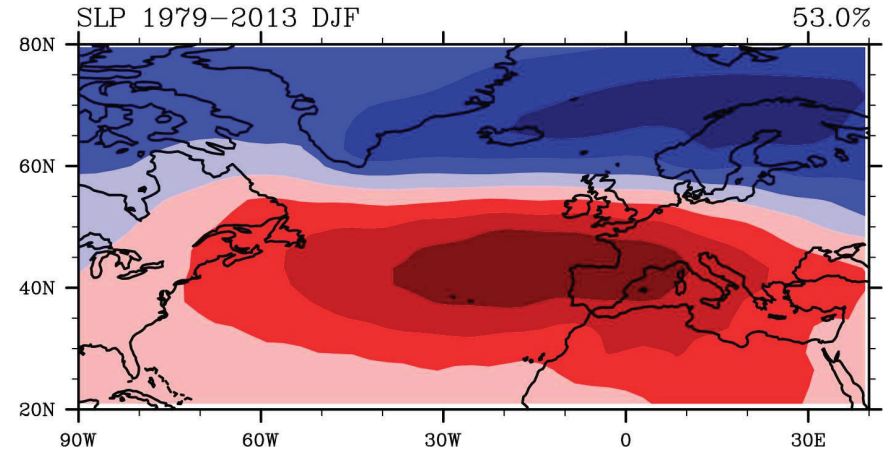

EOF 2

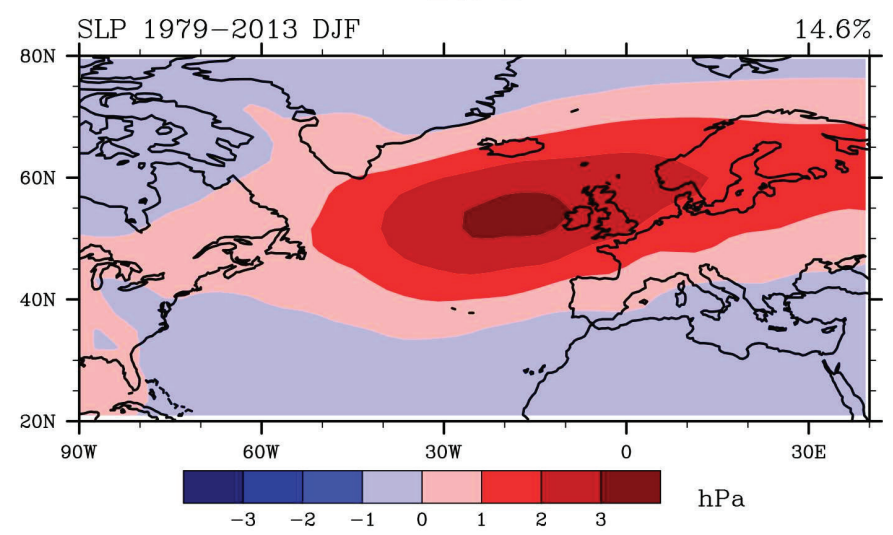

Figure 1. First two empirical orthogonal functions, EOF1 (top) and EOF2 (bottom), of the winter (DJF) mean sea level pressure (SLP) anomalies in the North Atlantic sector $\left(20-80^{\circ} \mathrm{N}\right.$, $\left.90^{\circ} \mathrm{W}-40^{\circ} \mathrm{E}\right)$ of the nudged simulation (1979-2013) and the percentages of the total variance explained. The patterns are displayed in terms of amplitude $(\mathrm{hPa})$, obtained by regressing the SLP anomalies on the principal component time series.

\section{ACPD}

15, 33049-33075, 2015

NAO evolution and tracer transport

\section{S. Bacer et al.}

Title Page

Abstract

Introduction

Conclusions

References

Tables

Figures

14

$>1$

4

Back

$>$

Close

\section{Full Screen / Esc}

Printer-friendly Version

Interactive Discussion 


\section{EOF 1}

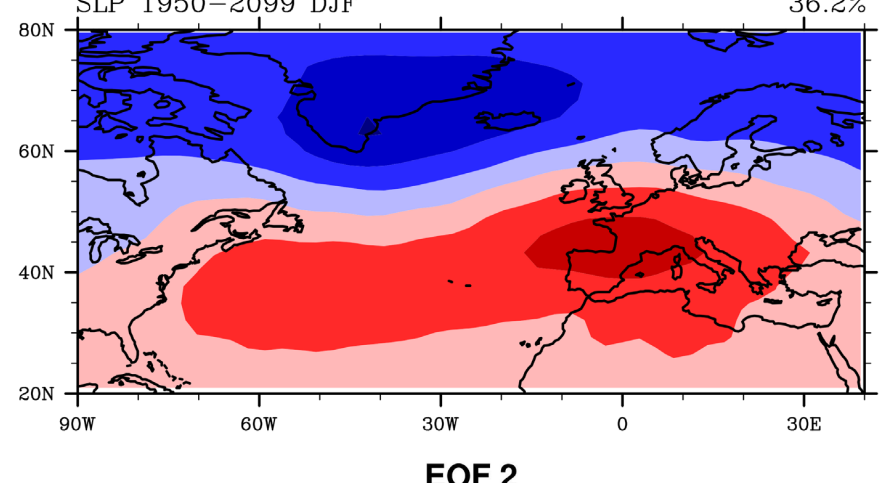

NAO evolution and tracer transport

\section{S. Bacer et al.}

\section{Title Page}

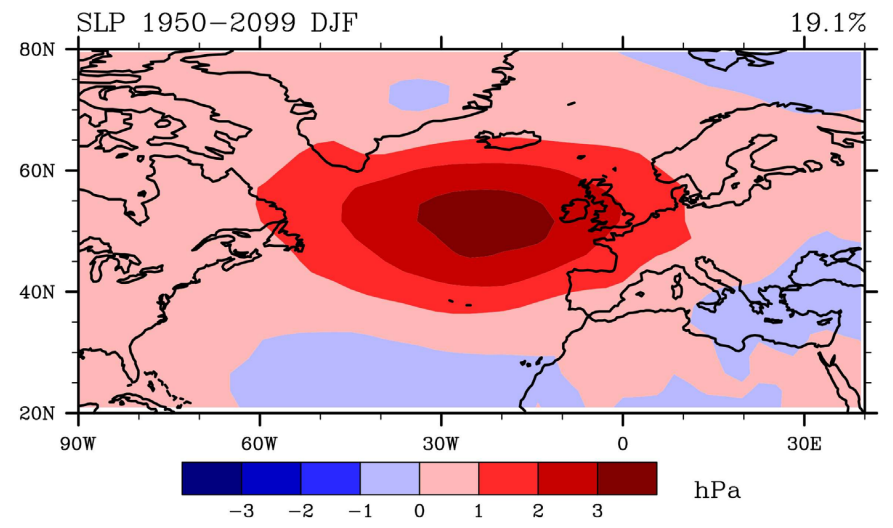

Abstract

Introduction

Conclusions

References

Tables

Figures

14

> I

4

Back

>

Full Screen / Esc

Full Screen / Esc

Printer-friendly Version

Figure 2. First two empirical orthogonal functions, EOF1 (top) and EOF2 (bottom), of the winter (DJF) mean sea level pressure (SLP) anomalies in the North Atlantic sector $\left(20-80^{\circ} \mathrm{N}\right.$, $\left.90^{\circ} \mathrm{W}-40^{\circ} \mathrm{E}\right)$ of the long simulation (1950-2099) and the percentages of the total variance explained. The patterns are displayed in terms of amplitude $(\mathrm{hPa})$, obtained by regressing the SLP anomalies on the principal component time series. 


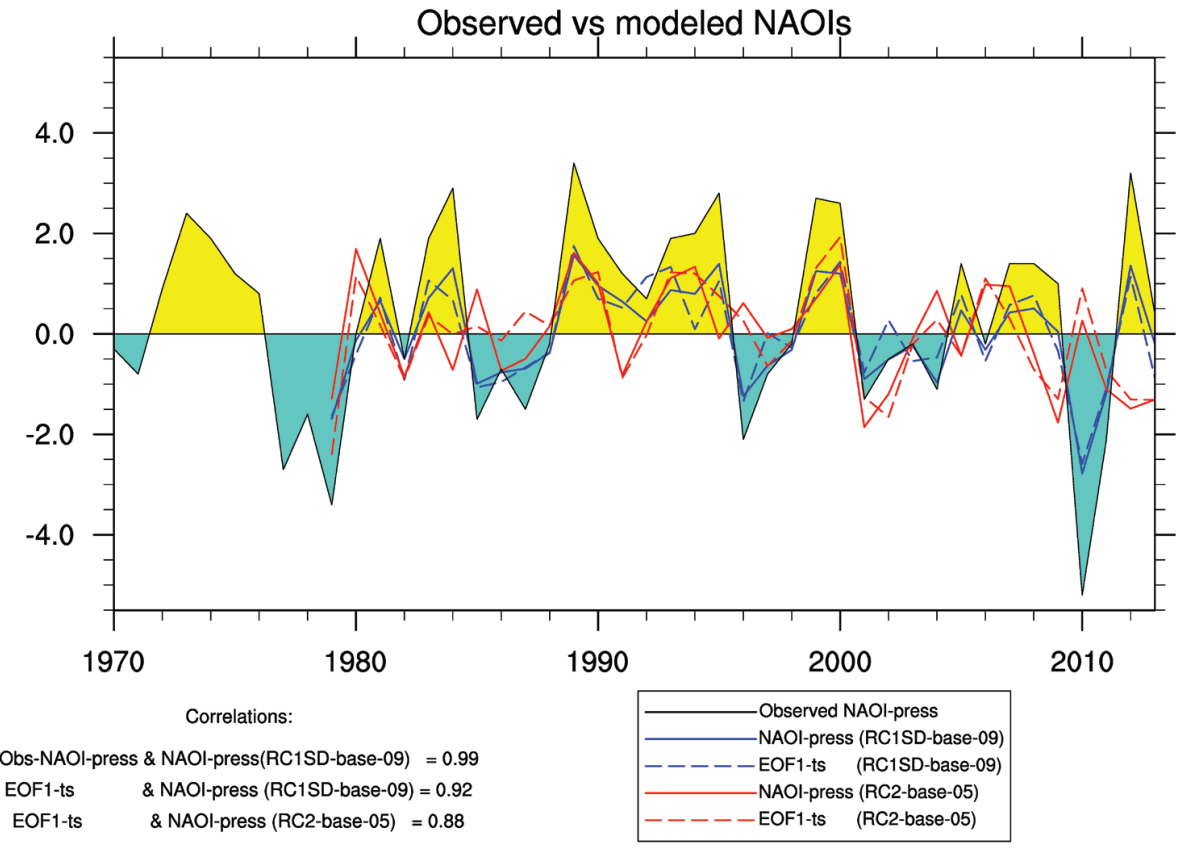

Figure 3. Time series of the observed NAO index based on the normalized SLP difference (Obs-NAOI-press) between Ponta Delgada and Stykkisholmur/Reykjavik (black line), the modeled NAO indices based on SLP difference (Modeled-NAOI-press) for the simulations RC1SDbase-09 (blue line) and RC2-base-05 (red line) and the principal component time series of the leading EOF (Modeled EOF1-ts) for the simulations RC1SD-base-09 (blue dashed line) and RC2-base-05 (red dashed line).
ACPD

15, 33049-33075, 2015

NAO evolution and tracer transport

S. Bacer et al.

Title Page

\section{Abstract}

Introduction

Conclusions

References

Tables

Figures

14

$\rightarrow$

4

Back

Close

Full Screen / Esc

Printer-friendly Version

Interactive Discussion 

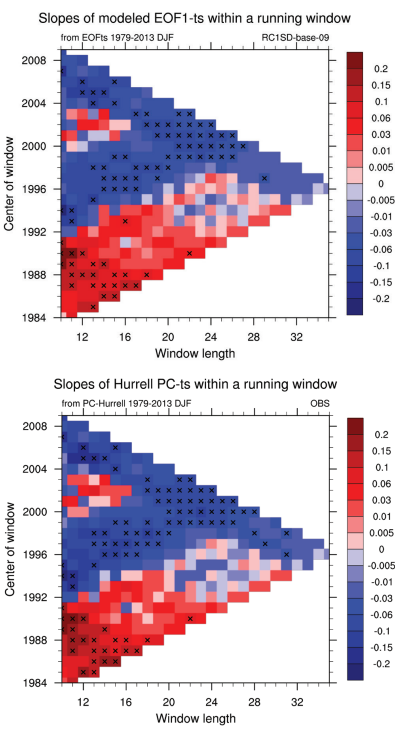

NAO evolution and tracer transport

S. Bacer et al.

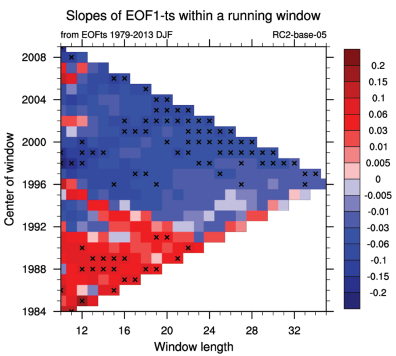

Figure 4. Linear regression coefficients of EOF1-ts based on RC1SD-base-09 data (top), PCts by Hurrell (center) and EOF1-ts based on RC2-base-05 data (bottom) computed in sliding windows with variable lengths. Plotted in the $x$ axis are the window lengths, in the $y$ axis the central years of the windows, and the regression coefficient values are expressed in $\mathrm{hPayear}^{-1}$ (see color legend). Points marked with a black cross indicate the $90 \%$ level of significance.

\section{Abstract}

Conclusions

Tables

14

4

Back

Close

\section{Full Screen / Esc}

Printer-friendly Version

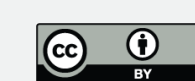




\section{Slopes of EOF1-ts within a running window}

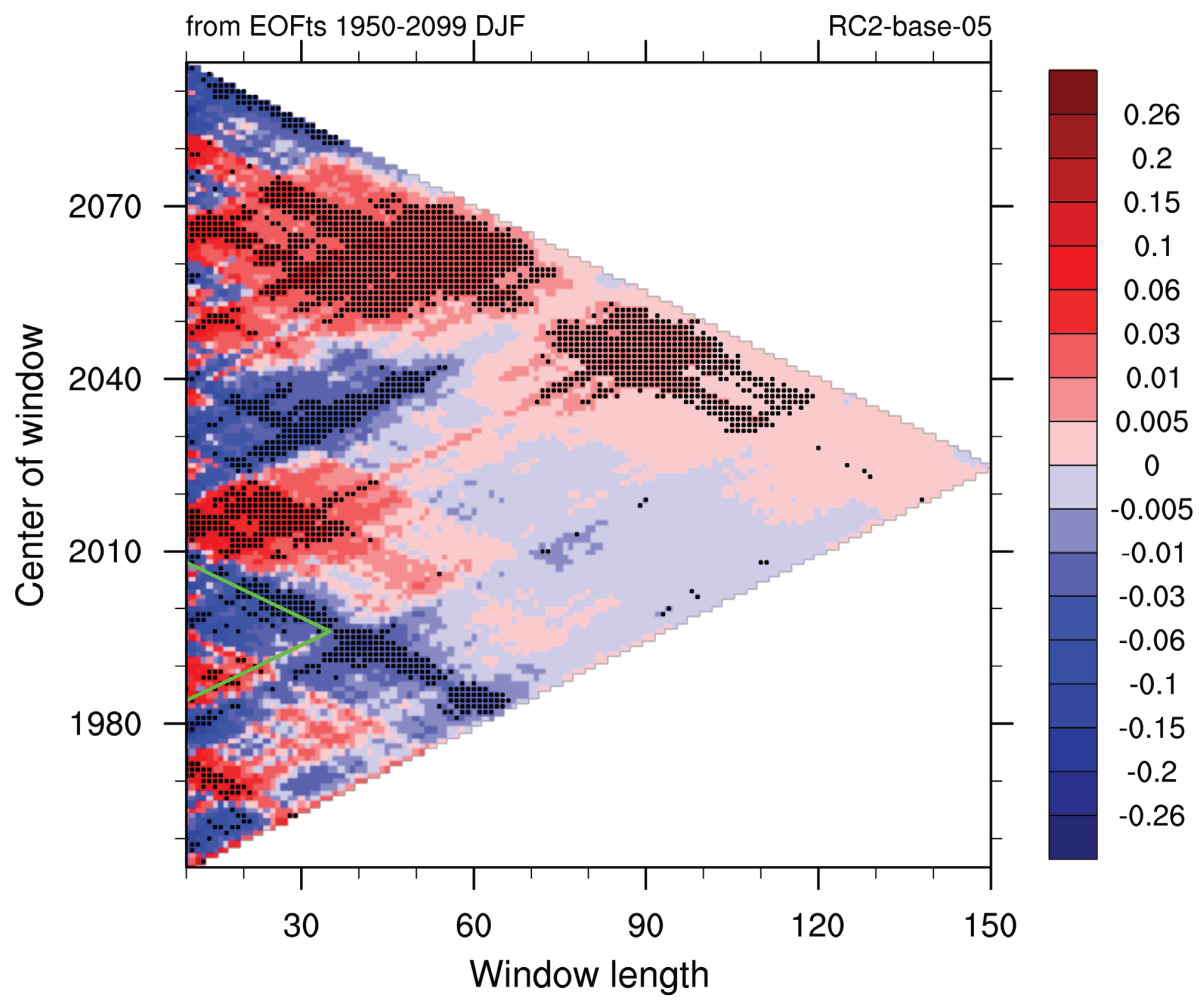

Figure 5. Linear regression coefficients in $\mathrm{hPayear}^{-1}$ (color scale) of the principal component time series of the EOF1 computed in sliding windows with variable lengths with RC2-base-05 simulation data; in $x$ axis there are the window lengths and in $y$ axis the central years of the windows (from 1955 to 2094). Points with a black cross indicate the $90 \%$ level of significance.
ACPD

15, 33049-33075, 2015

NAO evolution and tracer transport

S. Bacer et al.

Title Page

Abstract

Introduction

Conclusions

References

Tables

Figures

14

$>1$

4

Back

>

Close

Full Screen / Esc

Printer-friendly Version

Interactive Discussion 


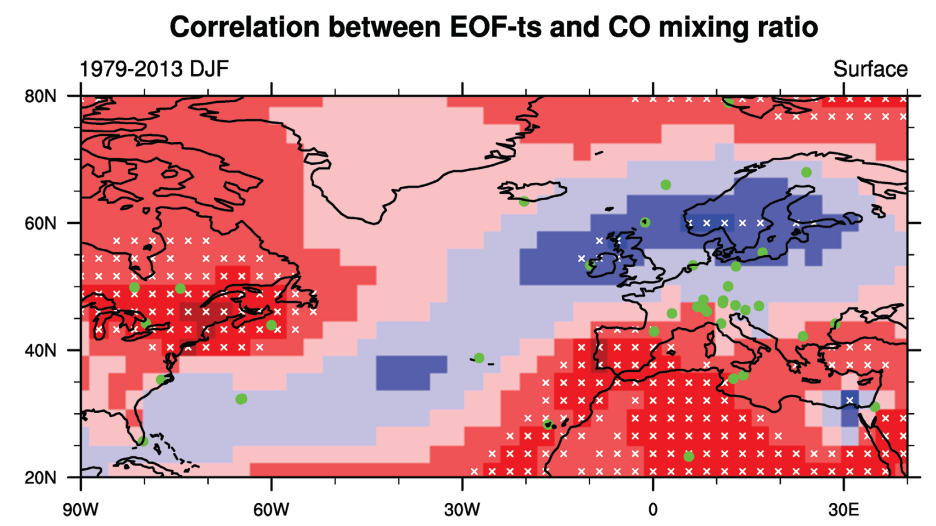

ACPD

15, 33049-33075, 2015

NAO evolution and tracer transport

S. Bacer et al.

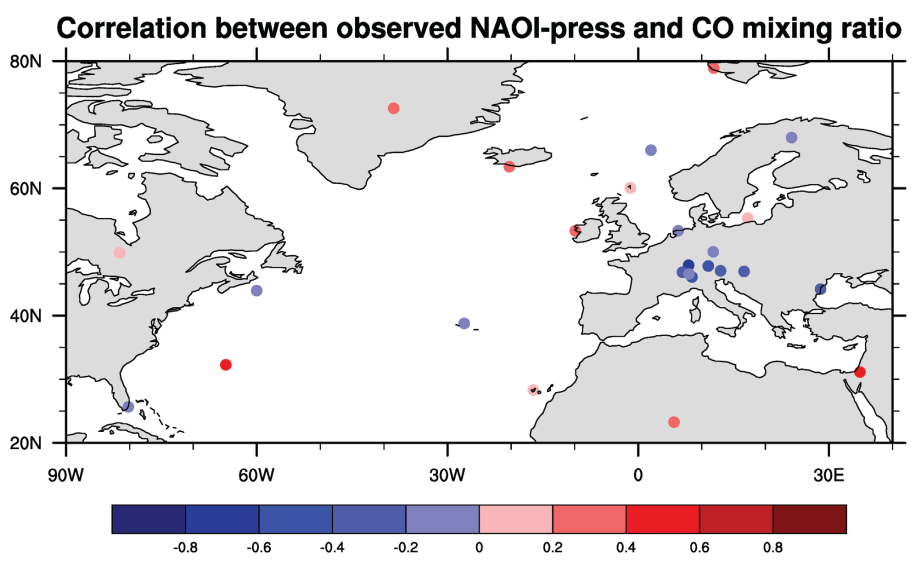

Title Page

Abstract

Introduction

Conclusions

References

Tables

Figures

14

> I

4

Back

$>$

Close

Full Screen / Esc

Printer-friendly Version

Interactive Discussion surface level with the principal component of the EOF1 time series for the nudged simulation (RC1SD-base-09); points with a white cross indicate local $95 \%$ level of significance. Bottom: correlation between observed DJF CO mixing ratio and PC-ts by Hurrell; circles correspond to the locations of the stations (also shown as green circles in the top panel). 
Correlation between EOF-ts and $\mathrm{CO} 25$ mixing ratio

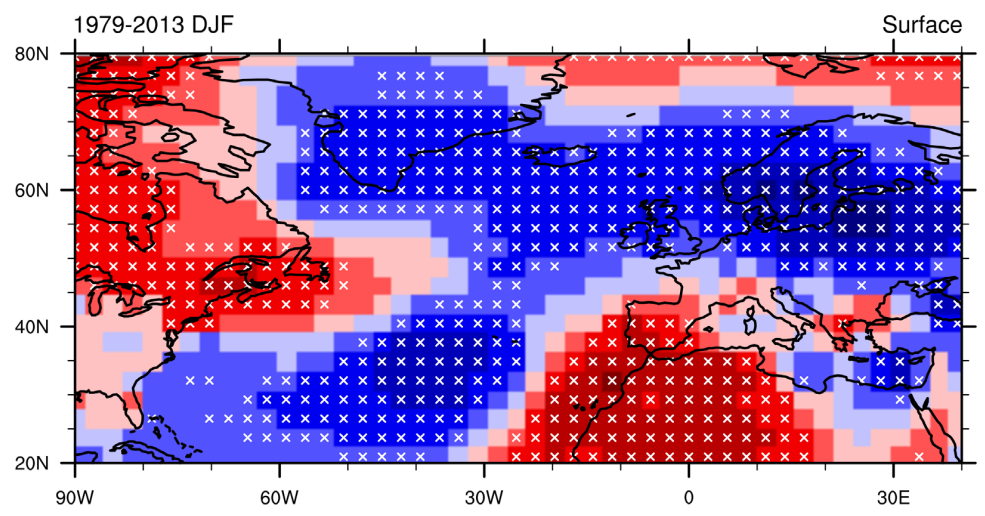

Correlation between EOF-ts and $\mathrm{CO} 25$ mixing ratio

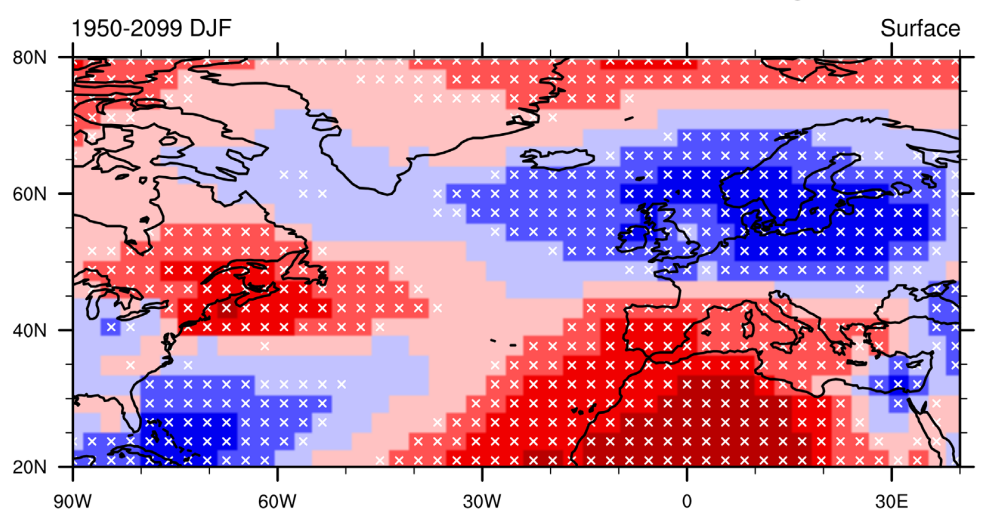

Figure 7. Correlation of winter (DJF) seasonal $\mathrm{CO}_{25}$ mixing ratio anomalies at surface level with the principal component of the EOF1 time series for the nudged simulation (RC1SD-base-09) (top) and for the long simulation (RC2-base-05) (bottom). Points with a white cross indicate the local $95 \%$ level of significance.
ACPD

15, 33049-33075, 2015

NAO evolution and tracer transport

S. Bacer et al.

Title Page

Abstract

Introduction

Conclusions

References

Tables

Figures

$1<$

$>1$

4

Back

$>$

Close

Full Screen / Esc

Printer-friendly Version

Interactive Discussion 